\title{
A CULTURA DA BATATA-DOCE: CULTIVO, PARENTESCO E RITUAL ENTRE OS KRAHÔ
}

Ana Gabriela Morim de Lima

\section{“Ra i mã Jàt hĩrõt!: Batata já brotou para mim!"}

O comentário das mulheres krahô pode ser etnográfica e analiticamente desdobrado. Batata não nasce simplesmente, ela brota e dá "para alguém". Antes escondidas embaixo da terra, as cabeças da Batata se tornam visíveis para a mulher se esta é vista como uma boa mãe, cuidadosa e generosa. Do contrário, a Batata não dá nada, se muda para a roça de outro e pode se vingar com doenças. Dotada de conhecimentos xamânicos e rituais, a Batata também tem toras, cantos e danças que foram apropriados pelos mẽhĩ antigos no tempo do mito.

"Se onde houver relação, ela existe para mim" (Lima 2005:88), nós nos deparamos então com a impossibilidade de haver espectadores absolutos e fora de contexto, de sujeitos e objetos pré-constituídos, de entidades e substâncias essencializadas. A partir destas colocações, o presente artigo aborda as relações cotidianas e rituais entre humanos e plantas por meio da etnografia do ciclo de vida da batata-doce cultivada pelos Krahô, recuperando temas centrais desenvolvidos na literatura dos povos Jê. ${ }^{1}$

Os Krahô, como os demais povos Timbira, se autodenominam "mẽhĩ": "os da minha carne", "pessoa" ou "índios como nós mesmos" (Nimuendajú 1946; Azanha 1984; Coelho de Souza 2002). Os Timbira pertencem à família Jê e ao tronco linguístico Macro-Jê. Habitantes do Cerrado, a Terra Indígena Krahô está localizada no nordeste do Tocantins.

"Jàt", ou simplesmente "batata" em português, é como os Krahô se referem à batata-doce (Ipomoea batatas). ${ }^{2}$ Eles conhecem aproximadamente 15 variedades locais, diferenciadas por critérios como coloração e textura da casca e da massa, semelhança morfológica com outras plantas e animais, origem, duração do ciclo, tempo de cozimento e formas de uso. ${ }^{3}$ Uma ciência do concreto, como formulou Lévi-Strauss (1989 [1962]), que opera através de uma lógica do sensível e expressa a observação metódica e experimental do pensamento indígena, a precisão com que reconhece as menores diferenças. 
Algumas variedades de batata-doce, assim como de milho, são alimentos importantes nos resguardos que visam à construção dos corpos dos parentes humanos, quando uma série de outros alimentos de origem animal e vegetal é proibida. A importância da batata-doce, entretanto, não se restringe à esfera alimentar: ela é cultivada enquanto "parente", pensa e sente, vê e canta o mundo. Veremos que, tão diversas quanto as suas variedades biológicas, são também suas intrincadas formas sociais: Batata-cabeça-filho (Jàt krã / Jàt kra); Batata-corpo-dona (Jàt); Batata-dona-mestre (Jàt jõ pahhi); Batata-espírito (Carõ); Batata-gente (Jàt hĩamã) etc.

As práticas e as concepções ameríndias, de modo geral, nos distanciam da narrativa dominante sobre a domesticação das plantas, como passagem do estado selvagem ao domesticado pela seleção artificial que, ao resultar em mudanças evolutivas nos fenótipos e nos genótipos da população descendente, torna a planta mais adaptada ao cultivo, aos usos e às necessidades humanas. Tal visão se fundamenta na divisão entre selvagem/natural e doméstico/artificial, corroborando a imagem do excepcionalismo humano e da natureza moldada pela cultura (Ingold 2000; Van Dooren 2012).

As teorias ameríndias ressaltam, por outro lado, que as plantas cultivadas são sujeitos vivos e não meras entidades biológicas passivas em face das intervenções humanas. O que nos aproxima de outras abordagens teóricas que evidenciam a relacionalidade e os processos coevolutivos (Arruda Campos 2016). Neste sentido, pode-se dizer que humanos e plantas cultivadas são "espécies companheiras" (Haraway 2003) e que "as plantas também domesticaram os humanos" (Van Dooren 2012), pois o processo não é unidirecional, tratando-se antes de uma "codomesticação" em que, nas interações humanos-cultivares, ambos são constituídos e transformados, afetam e são afetados. Busco aqui por em destaque as noções de "viver com" e "tornar-se com", formas de se relacionar que envolvem socialidades diversas (Haraway 2003). ${ }^{4}$

Batatas, portanto, não são boas apenas para comer e para pensar, elas são seres animados, agentes que compartilham suas vidas com os humanos. Da perspectiva krahô, esta relação pode ser vista como um processo de "aparentamento" mútuo entre plantas e humanos, envolvendo um íntimo engajamento corpóreo e afetivo que abarca a dimensão da criação, da troca e da predação. Cabe ressaltar que o parentesco vegetal é recorrente entre diferentes povos ameríndios, apresentando importantes variações do tema, sendo bastante comum as plantas serem cultivadas como filhos. ${ }^{5}$ Não se trata apenas de afirmar o modelo vegetal como uma metáfora para o parentesco humano, em termos de representações simbólicas e construções culturais, mas de pensar a extensão do parentesco para além do humano e, especificamente, as formas propriamente krahô de fazer parentes. 
Assim como quem a cultiva, a Batata possui vontades e estados de ânimo, pensamento, linguagem e socialidade. "Batata é gente" (Jàt hĩa mã) e, ainda que não seja "gente como a gente" (mẽhĩ), é cultivada enquanto parente (mẽikwỳ). E se as batatas possuem seus donos humanos, possuem também seus "donos não humanos" (pahhi), com os quais é preciso estabelecer uma negociação. Os saberes e as práticas krahô nos oferecem outros modos de conceber o cultivo das plantas, acompanhando a reconceitualização das noções de humanidade, natureza e cultura pela etnologia à luz das teorias indígenas, em particular as reflexões em torno dos conceitos de "animismo" (Descola 2005), "perspectivismo" e "multinaturalismo" (Viveiros de Castro 2002 [1996]; Lima 2005).

As espécies companheiras, porém, não se restringem ao par humano-batata, abarcando um verdadeiro "bestiário de agências" (Haraway 2003). As agricultoras não criam suas plantas num ambiente vazio, sendo que o cultivo na roça implica um processo de co-habitar envolvendo seres diversos. Essas interações, que fazem parte do cotidiano na roça, se tornam especialmente visíveis nos cantos e nas performances da Festa da Batata, por meio dos quais uma multiplicidade de seres contam, cantam e mostram seus jeitos de ser e de viver.

\section{Plantio e Nascimento}

\section{[...] Nós arrancamos.}

Quando alguém vai plantar, eu vou lá e pego algumas.

Eu cato as cabeças grandes da Batata pra moquear

e levo os filhos dela.

Meu esposo já vai capinando a roça

e trabalhando com a broca.

Eu vou esperar com os troncos ainda em pé, sem derrubar.

Então eu vou varrer embaixo

e fazer um buraco profundo

onde eu mesma escolhi e demarquei a terra.

Pronto!

Quando a lua está cheia,

eu vou enterrar para arrancar.

Então eu deixo lá as batatas plantadas,

e eles irão derrubar os troncos que estão por cima

e queimar. 
Então vão brotar para mim, assim...

Espalhando uma da outra,

vão se aproximar uma na frente da outra, se juntando.

Então as cabeças da Batata vão ficando ali nas ramas [...]

A fala é da anciã Marinete Haprej Krahô e foi registrada durante um plantio de batata-doce. ${ }^{6}$ Se as questões levantadas por Haprej são compartilhadas por outras mulheres krahô, é importante ressaltar que foram evocadas de uma perspectiva particular: como ela, Haprej, concebe a relação com suas batatas, pois cada agricultora tem sua experiência de roça.

Em geral, são as mulheres mais velhas e maduras, que já têm muitos filhos e netos, as especialistas no cultivo da batata-doce. "Batata gosta da mulher, e a mulher gosta da Batata. Ela está sempre mexendo, lembrando do rumo da Batata. A mulher anda no rumo do pensamento da Batata", disse o ancião Olegário Tejapôc Krahô.

O verão (estação seca) é o tempo ideal para colher e plantar batata-doce, entre os meses de abril e agosto. Os antigos ensinaram assim: as mulheres plantam as batatas no verão, no momento de abrir a roça nova, antes mesmo de os homens derrubarem e queimarem. "Mã kwỳ kjnĩare: a Batata gosta da roça queimadinha", diz o canto-fala da Batata, pois o enraizamento das ramas é mais rápido em temperaturas elevadas. A batata-doce também é preferencialmente plantada na lua cheia, para que as cabeças cresçam à imagem dessa lua, grande e redonda.

Há uma relação intrínseca entre "a Batata", Jàt na língua, ${ }^{7}$ e suas "cabeças-filhos", as raízes tuberosas comestíveis, chamadas de Jàt krã (cabeça da Batata) ou Jàt kra (filho da Batata). Cabe notar que a língua krahô distingue os nomes "alienáveis" ou "independentes", isto é, não necessariamente possuídos e que incluem objetos em geral, plantas e animais; e os nomes "inalienáveis" ou "possuíveis", que precisam especificar a quem se relacionam e incluem partes do corpo, termos de parentesco e certos objetos (Castro Alves 2004; Miranda 2014). ${ }^{8}$ Ainda que seja referenciada a alguém, a Batata é dotada de existência própria, enquanto as cabeças-filhos são entidades relativas: trata-se sempre da cabeça ou do filho de alguém, uma aproximação já notada por Tânia Stolze Lima entre os Yudjá, do corpo como uma realidade do mesmo tipo que as relações de parentesco (Lima 2002).

Ao longo de suas ramas, a Batata gera seus filhos que, ao se tornarem cabeças grandes, são dados em retribuição àquelas que as cultivaram. "Krã" é uma categoria central: cabeças são repositórios de memória, possuem faculdades criativas e férteis. Assim também se define a relação cerimonial entre os mẽkrãtũm (cabeças-velhas, mestres) e os mẽkrãtuw (cabeças-novas, 
aprendizes). Na fala feminina, o termo ganha ainda um duplo sentido, fazendo referência aos testículos masculinos.

Observamos aqui um caso particular dessa relação corpo-dono amplamente difundida na Amazônia (Costa 2007, 2010; Fausto 2008; Guerreiro 2015): a Batata é corpo-dona das cabeças-filhos, ela agrega, ou melhor, ela é essa multiplicidade, aparecendo na forma singular apenas no contexto de interação com um outro. Entre os Krahô, a noção de corpo-dono também pode ser compreendida à luz do conceito de pahhi, literalmente traduzido como "nosso osso", esqueleto central de sustentação do corpo, que denota a figura dos chefes que "encorporam" uma coletividade humana ou não humana. ${ }^{9}$ Em diferentes narrativas míticas e xamânicas, os pahhi dos animais e das plantas se manifestam enquanto espíritos-imagens, vistos como "gente" pelos pajés que se apropriam de seus conhecimentos.

Voltando ao cultivo, assim como as mandiocas e os inhames - também plantios geralmente femininos - as batatas-doces se reproduzem por propagação vegetativa (clones). Outras plantas, como o milho, a fava e o andu, se reproduzem de forma sexuada pela polinização cruzada (sementes) e são considerados plantios masculinos. Esses modos de reprodução contrastantes extrapolam a dimensão biológica do cultivo e trazem questões importantes para compreender o parentesco. ${ }^{10}$

Entre os Krahô, o plantio da batata-doce é circular: as covas onde são plantados os feixes da rama ou as cabeças brotadas fazem o desenho de um círculo. Ao contrário do milho, cujas sementes são plantadas em fileiras lineares, traços que atravessam a roça. As ramas da Batata crescem, se espalham horizontalmente e ao longo delas novas cabeças-filhos são geradas. Haprej conta:

[...] Eu plantei aqui separado

e a rama já vai se espalhando ali.

Então uma rama vem caminhando na direção da outra

já vai se juntando até ficar redondo.

Parece com aldeia, igual a essa!

Um caminho vem

e esse vem e aquele vem

e lá está aquele caminho circular das casas.

É assim que se faz:

você planta em círculo

e vai ficar desse jeito! (...)

O crescimento e a reprodução da Batata são semelhantes aos da aldeia circular. A aldeia-mãe cindida dá origem às aldeias-filhas, que se multiplicam 
sempre com a mesma "forma Timbira" (Azanha 1984). Formas sociais que remetem a uma multiplicidade, horizontal e pluricêntrica, como colocou uma mulher canela-ramkokamekra (timbira): "Aqui é assim: os parentes se espalham pela aldeia inteira como rama de batata" (Ladeira 1982:52).

A imagem de crescimento inspirada no mundo vegetal e usada para referir-se aos ascendentes e descendentes parece ser um fenômeno pan-Jê setentrional, como nota Vanessa Lea (2012:134). As ramas da batata-doce explicitam o esqueleto provido pela continuidade das linhas femininas. Por outro lado, como qualquer diagrama, este também tem seus limites e desvantagens, já que privilegia as linhas femininas, desconsiderando outras conexões agnáticas e modos de relação baseados na filiação, como coloca Coelho de Souza (2002:595). Outras imagens, como a do crescimento do pé de milho, do buriti e do brotamento complementam a análise.

Entre os Mẽbêngôkre, o termo genérico para os jovens é "broto novo", uma das consequências lógicas de representar as genealogias com os ancestrais na base e as gerações "descendentes" brotando para cima e para os lados (Lea 2012:102). Igualmente entre os Xikrin, as gerações mais novas são como ramos de uma árvore, crescendo e ramificando (Vidal 1977:25 apud Lea 2012:134). Entre os Apinayé, a imagem do pé de milho evoca a sucessão das gerações, seus diferentes graus de "maturação", com as espigas que crescem na parte de cima, geradas pelos velhos que ficam na raiz (Roberto DaMatta 1976). Entre os Panara, a palmeira de buriti "cresce no mesmo lugar de modo análogo à identidade clânica, definida pela fixidez espacial" (Schwartzman 1988); e entre os Xavantes, "clã" significa "raiz", "início", "raiz de árvore" (Maybury-Lewis 1967 apud Coelho de Souza 2002:266).

\title{
Crescimento e resguardo
}

\author{
[...] Então as cabeças vão ficando nas ramas, \\ eu não mexo enquanto está verde. \\ Quando a folha ficar vermelha pra mim \\ eu vou arrancar.
}

Pego um pouco de folha de urucum esfrego e dou banho e aí fica pra mim...

Ahh... Eu vou ter muitas batatas grandes juntas!

Então sua folha vermelha vai ficando visível.

Você vai apontar aquela madeira, igual mesmo facão e cavar.

Se você cavar com o facão, ela vai se esconder 
a Batata irá retribuir outra pessoa

então você não vai ter nada.

Mas se você cavar primeiro com a boa madeira,

só você terá muitas batatas, com barro branco

e terá as cabeças grandes assim...

Quando elas veem você pela primeira vez,

"êh, essa minha mãe que é boa pra mim!"

Essas coisas não são bicho, são gente...

Se você furar com facão,

elas irão embora por causa da dor

vão pra qualquer roça, roça do outro.

A Batata vai sentir muita dor,

não vai ficando para você.

Mas se cavar com o pau de madeira boa

vai ter muitas batatas aparecendo pra você,

rachando a terra com o barro branco em volta. (...)

[...] E depois vão moquear as cabeças

e as crianças vão comer.

Quando esfriar você come

não pode assoprar, não deve assoprar a cinza

deixa do jeito que está

você lava e amolece e depois come.

Se você fizer Huuu! Huuu! Huuu!

Ela vai retribuir muito na roça de outro

vai ter só raiz para você

somente aqueles fiapinhos...

A fala de Haprej revela como o cuidado com as plantas cultivadas se manifesta no resguardo de plantio, que remete às atitudes próprias aos parentes da família nuclear. Em convergência com as teorias ameríndias, observamos que o parentesco não é "dado", mas "construído": é preciso "fazer", "refazer" e mesmo "desfazer" os corpos dos parentes, humanos ou plantas (Gow 1997; Viveiros de Castro 2002; Coelho de Souza 2002). Como coloca Peter Gow, o parentesco pode ser pensado como a transformação de "Outros em Humanos" e de "Humanos em Outros" (Gow 1997:44).

Quando as cabeças estão maduras, as folhas da Batata se mostram vermelhas para Haprej, que as banha com folhas de urucum. A pintura de urucum tem um papel central na fabricação dos corpos, por exemplo, durante processos de iniciação e amadurecimento: crianças recém-nascidas, moças 
que tiveram sua primeira menstruação, jovens guerreiros, o corpo do morto. Um outro indicador sensível é o "barro branco" que surge quando as cabeças maduras racham a terra seca. Gestadas na escuridão, as batatas crescem, empurrando a terra até chegarem à luz, quando se tornam visíveis para a agricultora, se esta é vista como uma boa mãe.

A oposição entre maduro e não maduro também é central. Quando algo está maduro se diz caprec ("vermelhinho", "na cor do urucum"), como se diz também das pessoas belas e fortes. Quando algo não está maduro se diz ihtetet, traduzido por "filhote" ou ainda "transparente". Diz-se que uma pessoa está ihtetet quando ela está preguiçosa, cansada, fraca. Existe, além disso, todo um vocabulário comum entre as partes do corpo humano e vegetal: a batata tem cabeça / raiz principal (ihkrã), pele / casca (ihkà), osso / fibra (cahhi), braço / raiz absorvente (ihpar), olho / nó (ihto) etc.

Não se pode "mexer" nas batatas ainda verdes. O episódio final da história que conta sobre a viagem do herói mítico Hartãt ao extremo do mundo alerta sobre as consequências de mexer nos cultivos verdes e sem permissão da dona: dois jovens iniciandos comem as cabeças não maduras de inhame e perdem seus pênis e testículos, transformados em vaginas. A Batata também adoece se entra em contato com mulheres menstruadas, cujo sangue é considerado perigoso: suas folhas ficam amareladas, suas cabeças apodrecem e não crescem, assim como ocorre com as crianças e os rapazes.

Na colheita, as mulheres não podem levar apenas as cabeças grandes, abandonando as pequenas na roça, pois estas sofrem com a exposição ao sol. Elas também não gostam do facão, sentem dor. Antigamente, as primeiras batatas-doces da roça eram colhidas com um instrumento confeccionado pelos homens, feito de um tipo de madeira avermelhada, bela e resistente. As mulheres usavam esse instrumento para "caçá-las", procurá-las entre as ramas embaixo da terra, agachadas, furando, cavando e arrancando. ${ }^{11}$ Esse instrumento mimetiza as unhas do tatupeba (auxêt), um dos principais predadores da batata-doce, e incorpora sua habilidade para caçá-las. A colheita das cabeças da Batata, assim como do Inhame e da Mandioca, é um ato de apropriação que requer atenção, uma espécie de "caçada feminina". Além disso, as plantas também co-habitam com outros animais peçonhentos, plantas urticárias, espíritos sedutores e enganadores.

Durante o resguardo de plantio da Batata, a dona não pode comer tatupeba, pois ele vai atrás das cabeças novinhas, caçando-as e desenterrando-as com suas unhas pontiagudas. Também é proibido comer tatupeba na ocasião do nascimento do primeiro filho: se os pais comerem, a criança respira mal, fazendo "incoco, incoco...", barulho semelhante ao do tatupeba. Animal de hábito notívago e solitário, ele é temido por ser uma das formas corporais 
assumidas pelos espíritos comedores de cadáver. "Caçar tatupeba" é ainda uma metáfora sexual recorrente, usada pelas mulheres em busca de parceiros sexuais. O mito krahô de origem das aldeias circulares conta sobre as desaventuras de Auxêt pyryre, o tatupeba do pênis comprido (Melatti 1974a).

A oposição seco x úmido é igualmente relevante. A batata-doce usada no resguardo é preferivelmente de uma variedade mais seca, que não tenha muito "leite" (ihhôc), o "sangue" (caprô) da batata. Um dos objetivos do resguardo pós-parto e da furação de orelha dos jovens iniciandos é justamente secar o sangue e demais secreções decorrentes desses processos. A variedade conhecida como ját tycre (batata roxa) é bem seca e com ela as mulheres costumavam fazer uma farinha própria para o resguardo (jàt parin), que era também levada para as caçadas e grandes expedições. Depois de assada, descascada e amassada, a massa da batata é deixada na esteira de buriti para secar ao sol, onde é remexida até virar farinha. Se aquilo que se come "é gente", as plantas da roça precisam ser "desagentivadas" para serem consumidas, assim como ocorre com a caça (Fausto 2002:16), processo mediado pelas técnicas culinária (Lévi-Strauss 2004 [1964]).

A esteira (cahty) onde descansa a massa da batata é também a "cama do casal": trançada pelos homens, ela é um trabalho do marido para a esposa, assim como a farinha de batata é um trabalho da esposa para o marido e os filhos. Nos antigos rituais de casamento krahô, o jovem casal deitava-se entrelaçado na esteira nova, tecida pela família do noivo para a ocasião. A esteira era colocada na casa da família da noiva, onde o casal passa a viver junto, tornando pública a aliança. Abraçados em verdadeira comunhão, eles recebiam conselhos dos mais velhos. O noivo é lembrado que, a partir daquele momento, deve se separar dos seus pais, devendo olhar, sobretudo, para sua esposa e sua sogra (Nimuendajú 1946:123 apud Coelho de Souza 2002:435).

\section{A estrela-mulher e seus filhos-plantas}

A questão de respeitar o resguardo para os filhos, sejam eles humanos ou plantas, traz uma série de ressonâncias com o mito de Caxêkwyj, a estrela-mulher que trouxe as plantas cultivadas do céu, ensinando aos mẽhĩ os conhecimentos do cultivo e da culinária.

Caxêkwyj caiu do céu em forma de rã, virou mulher e se casou com um jovem solteiro, que a mantinha em sua casa dentro de um cesto ${ }^{12}$ pendurado no telhado. Ela queria ficar escondida em segredo, visível apenas para o marido, mas foi descoberta pela cunhada. Assim, Caxêkwyj passou a viver entre os humanos e ofereceu seus "filhos" para seu novo povo, as plantas cultivadas que ela trouxe do céu. Foi ela quem trouxe as mudas de 
batata-doce, amendoim, inhame, mandioca e outros vegetais, quem ensinou a cultivar o milho, a fazer a roça, o paparuto etc. Caxêkwyj veio de longe e seu casamento com um mẽhĩ realiza, assim, uma mediação entre mundos distintos: o céu e a terra, o alto e o baixo, o próximo e o distante, humanos e não humano. Porém, contrariando a regra da uxorilocalidade, foi ela quem se mudou para a casa do marido. Um dia Caxêkwyj ficou grávida e, quando a criança nasceu, nenhum dos pais respeitou o resguardo. A criança morreu e Caxêkwyj resolveu se vingar. Ela foi para o mato, tirou a água do timbó e deu para os homens, que morreram envenenados. Então, Caxêkwyj abandonou a aldeia e voltou para o céu, sua antiga morada.

Este episódio final é significativo para pensar a relação entre as mulheres e a Batata: se a agricultora não cuida de suas cabeças-filhos, a Batata sente "raiva" e pode causar doenças ou abandoná-la, não "dar mais pra ela". A Batata se muda para uma nova roça e passa a "retribuir" outra pessoa. Estabelece-se aqui uma relação social que pode ser bem sucedida ou não. Como coloca Belaunde (2001:30), o estudo da fertilidade é inseparável do manejo das emoções e das atitudes, que podem levar à destruição da sociabilidade.

A mulher "cria" as cabeças da Batata e esta "dá" seus filhos para a mulher, isto é, "alimenta" os parentes humanos com seus próprios filhos. Do mesmo modo, Caxêkwyj traz seus filhos-plantas do céu e os oferece à cunhada, sendo este o marco de uma alimentação propriamente humana. Para além da filiação, a relação de afinidade feminina é central. A troca e a circulação dos filhos-plantas entre as mulheres afins promovem a diversidade, a fertilidade e a beleza das roças, permitindo às mulheres krahô, ainda nos dias de hoje, enriquecerem o legado deixado por Caxêkwyj em suas roças. Veremos adiante que, na ocasião da Festa da Batata, são ativadas as redes de troca entre as casas maternas, por onde circulam sementes, alimentos, pessoas, nomes, bens materiais e imateriais.

Em síntese, Caxêkwy está para sua cunhada assim como a Batata está para a agricultora, relação marcada pela alteridade e pela troca entre mulheres de diferentes casas maternas. Ao mesmo tempo, Caxêkwyj está para as plantas cultivadas assim como a Batata e a agricultora estão para suas cabeças-filhos, relação de partilha e resguardo, que ressalta o papel dos genitores-criadores. As cabeças e os filhos são gestados, criados e amadurecidos por suas donas-corpo-mães, para serem apropriados por outras casas, onde farão mais parentes.

Ao adentrarmos na etnografia da Festa da Batata, veremos como os hôxwa (palhaços-abóboras) e suas mães (donas das batatas) personificam essas relações. São as parentes maternas dos hôxwa que devem "dar" as 
primeiras batatas colhidas em suas roças para a festa. Assim, as cabeças-filhos saem das roças das mães dos hôxwa e circulam pela aldeia por meio de uma extensa rede de trocas entre as diferentes casas maternas.

\section{A “indústria” da Batata}

Muitas atitudes podem deixar os cultivos raivosos. A relação fundada na troca-dádiva não consiste em generosidade permanente ou está isenta de retribuição, de modo que também devem ser consideradas as consequências da quebra do princípio da reciprocidade: a contrapredação da Batata sob a forma de doenças, morte e abandono. Como diferentes autores notaram acerca da "ética da caça" na Amazônia, também a "ética do plantio" remete ao perigo da inversão de posições entre "aquilo que come" e "aquilo que será comido" (Vilaça 1992; Lima 1996; Viveiros de Castro 2002 [1996]; Fausto 2002).

A Batata tem "carõ", termo que aceita diversas traduções, dentre elas "alma", "espírito", "imagem" ou qualquer reflexo especular (sombra, foto, vídeo, imagem onírica etc.). O carõ habita o corpo, embora possa dele se ausentar em sonhos e doenças; é o que sobrevive à morte corporal e social da pessoa; e é na sua forma coletiva (mẽcarõ) que aparece mais comumente o sentido de "alma ou espírito dos mortos" (Carneiro da Cunha 1978:10). Mais do que simples projeção, o carõ é concebido como princípio agentivo, isto é, como atuação do duplo: "a presença da ausência" de um corpo em relação ao qual ele é autônomo, porém intrinsecamente relacionado (Vilaça 1992); ou ainda aquilo "que remete ao objeto sem, no entanto, se confundir com ele" (Carneiro da Cunha 1978:11). O duplo revela a intencionalidade dos seres, possui uma existência móvel, podendo se transformar e assumir formas corporais distintas. Os Krahô concebem que os carõ de certas plantas e animais são responsáveis por doenças, ao mesmo tempo em que são eles dotados de conhecimentos xamânicos de cura.

Entre os Krahô, não são raras as histórias sobre a braveza e a sedução da mandioca, a periculosidade do inhame sucuriju, entre outras envolvendo feitiços colocados pelas plantas. A narrativa de um velho pajé sobre a "indústria da batata", em particular, atrai a nossa atenção. Hapuhhi Krahô contou que estava sozinho cozinhando na casa da roça, comeu as cabeças da Batata recém colhidas e passou mal. Ele virava no chão de tanta dor quando viu o carõ da Batata, que lhe ofereceu folhas para passar no corpo: "Você quer?". Então, Hapuhhi conseguiu enxergar tudo: 
Eu via tudo como lanterna, eu via tudo de longe, o povo no pátio e também os mẽcarõ. Eu aceitei a indústria da Batata. Quando planta o alimento, não pode mexer no tempo errado. Se mexer, ela vira contra você, ela vai tentar fazer você de pajé. Se mexer no tempo errado, ela não gosta e faz doença em você. Dor de cabeça, febre. A pessoa sofre de dor até conseguir virar pajé. Se você não virar pajé, você morre. Se transformar em pajé, cura e levanta na mesma hora, não sente mais dor. Quando ela se transforma em pajé, a dor some. Se o sangue da pessoa é ruim, ela não vira e só sofre. Depois de ser pajé, não pode comer as coisas assadas no fogo. A visão vai ser forte. Eu não como mais batata, nem macaxeira, nem assada nem no caldo.

Melatti (1974b) notou que as experiências xamânicas individuais são elaboradas discursivamente como um reviver do mito de Tyrcrẽ, o pajé krahô prototípico. Tyrcrẽ foi abandonado doente e sozinho pela mulher, mas foi socorrido pelo povo-urubu que o levou até o mundo celeste, onde foi alimentado pelo povo-gavião. Lá, ele presenciou os conhecimentos xamânicos e os rituais do chefe gavião-real e deles se apropriou, trazendo-os para a terra.

Temos aqui uma outra dimensão do parentesco entre humanos e plantas. Para além dos atos de sociabilidade cotidiana que envolvem a criação e a troca, a predação e o xamanismo também estão relacionados ao fazer parentes, embora constituam processos distintos. Como vimos anteriormente, no plantio e no crescimento, as cabeças da Batata são cultivadas como filhos e, no resguardo pós-parto e de furação de orelha, suas qualidades sensíveis atuam na construção do corpo dos parentes humanos, desde que devidamente transformadas em alimento. Já no processo xamânico relatado por Hapuhhi trata-se, ao contrário, da desumanização do corpo pela identificação com o "outro" ingerido, mais precisamente com seu duplo (o carõ), onde reside justamente a condição de possibilidade para se virar pajé (wajaka), que se completa por meio do processo de aparentamento com o "chefe" (pahhi) da planta ou do animal. Isso significa se apropriar das disposições específicas do espírito agressor, sendo a familiarização um modo de "fazer parentes out of others" (Vilaça 2002).

Entre os Krahô, quando o espírito agressor é familiarizado e o doente transformado por meio da iniciação xamânica, este que vira pajé passa a se referir àquele que se torna seu espírito-auxiliar como japar (sobrinho), sendo chamado por ele de keti (tio cruzado). Assim também são chamados os filhotes da presa morta pelo caçador, que é levada e criada na aldeia pelas mulheres: ipi japar xà. Se a familiarização inverte a relação de predação inicial (Fausto 2002), observamos no caso Krahô que esse processo mobiliza mecanismos próprios às relações de nominação, o que é recorrente também nas narrativas míticas que contam a origem da apropriação de objetos, festas e cantos, como veremos abaixo. 


\section{Mito de origem, transmissão e circulação de conhecimentos}

Os índios plantaram a roça e saíram para o mato. Ninguém ficou em casa. Passaram três meses fora da aldeia, comendo buriti, macaúba, bacaba, caçando. Mandaram um txikate [mensageiro]. O governador lhe disse: "Agora você vai ver se nossos legumes já estão maduros". Ele foi. Já era tarde, negócio de três horas da tarde. Já estava perto da aldeia. Batata, melancia, abóbora, inhame estavam gritando. Viraram gente [...] (Diniz Krahô apud Melatti 1978:193-194).

[...] Batata era gente. O Milho também era gente, Banana era gente, Mamão era gente, Amendoim, Batata, Inhame eram gente mesmo. [...] Então ele viu. As coisas chamaram ele: "Ikrãtũm, ikrãtũm, vem, vem! Já que você já viu seus filhos, seus netos, já que você já viu a gente, vem, vem! E escute, escute bem mesmo!" [...] (Zacarias Ropkà Krahô apud Morim de Lima 2016:240-242).

No tempo do mito, os antigos tinham o costume de deixar suas roças plantadas e abandoná-las, saíam para o mato por longos períodos, para caçadas e coleta de frutos. Na época da colheita, eles mandavam um "mensageiro" para saber se os legumes já estavam maduros. Naquele dia, quando ele chegou na roça, as plantas cultivadas estavam maduras, tinham virado gente e faziam a festa. A narrativa prossegue com detalhes sobre as ações rituais e os cantos da Festa da Batata.

No mito, tudo é "gente", as dimensões corporais e espirituais não se ocultam reciprocamente, imersas em regimes de metamorfoses múltiplas (Viveiros de Castro 2002:419). O mensageiro era também um pajé: viu, ouviu, aprendeu e lembrou de tudo. Embora os regimes de transmissão e circulação de conhecimentos xamânicos e rituais sejam diferenciados ${ }_{1}{ }^{13}$ ressaltamos aqui suas interseções.

Nota-se o papel central conferido aos sentidos na apropriação do conhecimento, em especial a visão e a audição (Seeger 1981; Crocker 1990). A capacidade de ver pode ser traduzida por hõmpu; de ouvir, por campa. Mas o desenvolvimento de uma "boa visão" e de uma "boa escuta" se dá através da atenção e da observação cuidadosas, capacidades desenvolvidas por certos especialistas. Nestes casos, se diz: "Imã irit xà pej, imã hũpar xà pej" ("boa visão existe para mim", "boa escuta existe para mim"). Como colocam Borges e Niemeyer:

Para se tornar um cantor, é preciso antes saber conhecer (isto é, saber ouvir e furtar, guardando no krã [cabeça] o que se escuta, tal como proferiu Hartãt), e para se tornar um wajaka [pajé], é preciso antes poder saber, isto é, ter aberta 
uma via subjetiva de diálogo com outras agencialidades (tal como aconteceu com Tyrkrẽ). Entre o saber conhecer e poder saber reside a capacidade de trazer para o coletivo mehim outras agencialidades (Borges \& Niemeyer 2012:273).

Os modos ameríndios de conhecer não são desconectados da experiência corporal, multissensorial e perspectivista, e estão relacionados ao ritual e ao xamanismo. As percepções e as afecções corporais são entranhadas de valores morais e estéticos, indispensáveis à aquisição de saberes (Carneiro da Cunha 2009:365). O "saber-ouvir e o ver além" operam enquanto aberturas na interação com os "outros" - plantas, animais, espíritos etc.

Um ponto central na mitologia ameríndia é a relação de apropriação com o que vem de fora, como notaram diversos autores. ${ }^{14}$ Os rituais, por sua vez, são momentos centrais na atualização, na captura e na transmissão desses conhecimentos. Os Krahô "pegaram" suas festas, objetos, cantos e conhecimentos de cura de outras agencialidades não humanas. Se os bens materiais e imateriais possuem seus donos-mestres num mundo de múltiplos domínios (Fausto 2008), os especialistas rituais aparecem não como proprietários individuais de um saber, mas como agentes que realizam as mediações com a alteridade plural. Ao externalizarem seus conhecimentos, eles os fazem circular, permitindo sua potencial (re)apropriação por outros (Borges \& Niemeyer 2012).

O mito e o ritual evidenciam ainda as relações entre os "cabeças velhas" e os "cabeças novas" na atualização e na transmissão de certos conhecimentos. A Batata chama o mẽhĩ mensageiro de keti (tio materno-avô / nominador) ou mẽkrãmtũm ("cabeça velha"), e é chamada de mẽkrãmtuw ("cabeça nova"), termo análogo a japar ou ipantu (sobrinho-neto / nominado). A mesma terminologia é usada entre os pajés e seus espíritos auxiliares, como vimos anteriormente.

Essa relação aparece como uma constante nos mitos de origem krahô. Ela dá forma à transmissão de conhecimento ritual, própria à relação de nominação (ainda que não restrita a ela). Os nominadores podem ser qualquer parente que ocupe a posição de irmão da mãe, avô materno ou paterno (ego masculino); irmã do pai, avó paterna ou materna (ego feminino). ${ }^{15} \mathrm{O}$ nome está associado a papéis rituais especializados, sendo a identidade onomástica criadora de uma identificação profunda entre o nominador e o nominado, tanto na esfera cerimonial quanto no círculo do parentesco (Melatti 1970, 1976). Ao receber um nome, a pessoa adquire também os parentes do seu nominador e passa a ocupar uma posição específica numa rede de parentesco não restrita ao seu próprio âmbito doméstico. 
A relação de nominação não se restringe aos nominadores e nominados, mas abrange aqueles que "trocam nomes", preferencialmente irmão e irmã classificatórios nascidos em diferentes segmentos residenciais. Segundo Maria Elisa Ladeira (1982:52), a nominação é um mecanismo de aproximação dos parentes que estão se distanciando, ao passo que sua não conversão abre a possibilidade para a aliança matrimonial. ${ }^{16}$ Cabe notar que esta é também a principal estratégia de "familiarização" do estrangeiro-branco (cupẽ) que chega à aldeia: ele ganha um nominador, um nome, e por meio dele, uma rede de parentes. A nominação aparece, portanto, como uma mediação possível, e o nome, como operador sociocosmológico importante das trocas com diferentes figuras da alteridade.

Melatti $(1970,1976)$ foi um dos primeiros a chamar a atenção para o aspecto dual da pessoa entre os Krahô: os genitores (paralelos) produzem o corpo, isto é, a "carne" (nĩ), através da partilha de substâncias; os nominadores (cruzados) transmitem o nome (prỳ), constitutivo da persona social. ${ }^{17}$ Carneiro da Cunha, ao analisar o contraste feito pelos Krahô entre sangue (caprô) e osso (hi), define o primeiro como um líquido corporal que pode aparecer e desaparecer (seu total desaparecimento, inclusive, consuma a morte da pessoa), sendo a regulação do seu fluxo o objetivo dos resguardos feitos pela família nuclear; já o segundo, corresponderia ao que há de sólido e perene, "os ossos parecem ser o sustento de uma noção de persona, de um conjunto de direitos e deveres" (Carneiro da Cunha 1978:110).

As análises de Melatti e Carneiro da Cunha nos levam a sugerir a associação entre ossos e nomes enquanto equivalentes à persona social. Em sua revisão crítica, Coelho de Souza ressalta que a percepção do dualismo genitores x nominadores acabou sendo generalizada na oposição entre corpo $\mathrm{x}$ nome, quando na verdade estes constituem momentos diferentes de um mesmo processo de produção de corpos de parentes humanos (Coelho de Souza 2002:477-478). A autora propõe uma importante reconceitualização desses termos, associando o nome também à pele (kà) e à alma (carõ):

O nome, de um lado, é "corpo", mais especificamente, "pele". Esse aspecto do nome, sugiro, corresponde à objetificação das relações que constituem a pessoa como parente [...] Mas o nome é também, sob outros aspectos, "alma": ele sobrevive à morte - é, como chama a atenção Melatti (1978:127; Lea 1986:380-382), uma parte "durável" da pessoa - e está ligado ao ritual e a seus personagens. [...] O que está em jogo neste caso é o nome como princípio de transformação: como aquilo que conecta a pessoa à esfera cerimonial, onde se reencena e reenvoca o regime metamórfico do mito (Coelho de Souza 2002:574) 


\section{Jàtjõpĩ: a Festa da Batata}

A Festa da Batata ocorre geralmente entre abril e junho, tempo da colheita da batata-doce, e marca a passagem da estação chuvosa (inverno) para a seca (verão). Os rituais fornecem uma concepção concreta e não abstrata do tempo, fundamentada no dualismo, na alternância e na circularidade (Melatti 1978; Borges 2004). O calendário agrícola e sazonal é composto pelos rituais associados à batata-doce e ao milho, que expressam a homologia entre os ciclos ecológicos, sociais e cosmológicos. Amjīkĩn é como os krahô se referem as suas festas, termo que pode ser traduzido por "alegrar-se" (Melatti 1978:14). ${ }^{18}$ Os rituais alegram as pessoas e alegram também os "donos da festa", os "donos das substâncias", "animados" no duplo sentido da palavra (Lagrou 2007).

Na transição da estação chuvosa para a seca, o partido do Catãmjê (inverno/chuva/oeste/poente/gavião/horizontal) repassa o governo da aldeia para o partido do Wakmejê (verão/seca/leste/nascente/periquito/vertical). "Partido" é como os Krahô chamam em português aquilo que os estudos jê denominaram "metades cerimoniais". Na Festa da Batata, também são acionadas as relações geracionais entre os partidos do Harãcatejê (oeste/ poente) e Kyjcatejê (leste/nascente), que disputam a corrida com as toras da Batata, assim como as relações entre as plantas de crescimento horizontal e vertical, que participam da cantoria da Batata.

Um tema central dos estudos Jê refere-se à complexidade socioritual desses povos, conhecidos pelo fenômeno do "multidualismo". A discussão é longa e remonta a diversos autores ${ }_{1}{ }^{19}$ de modo que no espaço deste artigo retomaremos apenas pontualmente algumas questões. A primeira delas se refere à aldeia circular Jê e sua dinâmica entre o dualismo concêntrico projetado na oposição entre o pátio central/casas maternas, implicando um prolongamento ao exterior - e o dualismo diametral - projetado no pátio, dividindo-o internamente em "pares de metades opostas, complementares e assimétricas" (Lévi-Strauss 1974 [1952]).

A segunda, anteriormente discutida, refere-se à projeção do dualismo na noção de pessoa: os papéis dos genitores e nominadores na construção dos corpos dos parentes (Melatti 1970, 1976). A Festa da Batata é um ritual que atualiza as alianças matrimoniais, as relações de filiação e de nominação, o que se estende para além do parentesco humano, abarcando os parentes vegetais e as relações com diversas figuras da alteridade.

Observamos que os "partidos", "metades" ou "grupos" cerimoniais são antes configurações relacionais entre pessoas-plantas-animais-coisas-espaços-temporalidades-fenômenos que se associam e se diferenciam entre 
si em função de certas características, comportamentos, estados de ânimo, formas de habitar o mundo, ritmos e movimentos. Relações estas que são atualizadas em determinados eventos rituais e em outros não. A reificação das noções de metades enquanto "opostos complementares em equilíbrio dinâmico" e de grupos enquanto "todo composto por partes" (Maybury-Lewis 1979) acabou por criar a imagem das sociedades Jê como totalidades fechadas, internamente segmentadas e autossuficientes.

Seguindo a reflexão crítica mais recente (Coelho de Souza 2002; Gordon 1996), buscamos aqui repensar essa imagem por meio da qual as etnografias jê foram construídas, ainda que em determinados momentos não seja possível abrir mão da terminologia clássica. Adiciona-se a isso a crítica feminista que, incidindo sobre a análise das redes de aliança e nominação, possibilitou uma nova perspectiva sobre o material jê (Lea 1986; Ladeira 1982). Feita esta breve introdução teórica e conceitual, passemos à etnografia da Festa da Batata. ${ }^{20}$

Nos dias que antecedem a festa, os hôxwa escolhem a árvore, cortam e esculpem a tora de madeira: o pàrti ("tora grande") ou játjõpĩ ("tora da Batata"), de onde vem o nome do ritual na língua. Este é um trabalho masculino e, ao longo da empreitada, eles passam o tempo no mato, sendo alimentados não por suas esposas, mas pelas parentes maternas. Os hôxwa, palhaços cerimoniais que são gente-Abóbora no mito, têm um papel central na Festa da Batata.

Enquanto os hôxwa preparam as toras, as parentes maternas dos jovens recém-casados se dedicam à preparação dos paparutos, a comida cerimonial krahô, um bolo de mandioca com carne, enrolado na folha de bananeira e cozido embaixo da terra. Ao entardecer, na eminência da festa, é possível avistar de algumas casas da aldeia a fumaça dos paparutos assando, indicando que ali onde há fogo há "casamento".

No nascer do sol, os homens Harãcatejê e Kyjcatejê realizam a corrida de revezamento com a tora da Batata. A corrida é precedida pela performance do mestre ritual, que canta em tom baixo, com uma postura esquivada, dançando na frente das toras, dirigindo-se a elas. Ele não pode cantar alto, seu dizer não é para ser ouvido por todos os presentes. É um canto perigoso, explicou Getulio Kruakraj:

A voz dos espíritos é leve e baixinha, a nossa é pesada. A tora da Batata é do mẽcarõ, não é do mẽhĩ. O pajé que inventou de mostrar, o povo pegou e faz até hoje. Canto da tora da Batata é dos espíritos, por isso que o próprio mestre não canta alto. Canta é baixinho. Não é todo mundo que canta essa cantiga que engana, ela te engana com qualquer coisa... (Getúlio Kruakraj Krahô). 
A corrida começa na mata, corta o caminho radial e termina no centro da aldeia. Ao longo do trajeto, alguns velhos animam os corredores: "jêpapapa... hôôôôôôô... crowti, crowti... hôôôôôôô..." (cunhado, fique atento... hôôôôôôô... a tora é pesada... hôôôôôôố). Assim que a tora cai no centro da aldeia, os paparutos são trocados no pátio pelas famílias dos jovens recém-casados e que ainda não tiveram filhos, tornando "pública" a aliança entre os segmentos matrilocais. Simultaneamente, diferentes personagens rituais se encontram no caminho circular, e entoam os seguintes cantos: pjcajkô ("árvore cacha-morro"), pori krere ("buraquinho de bacaba") e jêjêj ("choro dos mortos").

A cantoria dá a volta no círculo da aldeia e as parentas maternas acompanham, carregando cabaças cheias de água, banhando e refrescando os cantores, ato que expressa a "solidariedade" entre os consanguíneos (Melatti 1978). É nesse momento que, ecoando das casas, as mulheres podem ser ouvidas chorando a saudade de seus mortos, geralmente aqueles parentes que se apresentavam na festa. Estes também choram sua saudade dos vivos, num canto que vem de aqui e alhures, como explica Zé Miguel Cõhc:

[...] o pajé conta que os mẽcarõ ficam andando, né? Quando é de dia, ele fica em algum lugar frio ou algum tronco grande, árvore grande, ele fica encostado naquela árvore. Pode se transformar em algum pássaro ou sapo também. Transforma e fica lá na sombra, quietinho. Então os mẽcarõ ficam ali. E assim, o canto do jêjêj conta como seu keti [nominador] fica como alma, porque o keti pode ouvir que você está cantando... seria como ele cantar pra você. Mas não tem como cantar, então ele fica chorando lá. Então, quer dizer que ele, o cantor, fica pedindo ao keti para ajudar ele, para ensinar mais alguma coisa na cabeça, ou chorar-se. Porque alma também chora. É assim que o jêjêj conta, um lembra do outro e chora.

No entardecer, a cantoria da Batata percorre o caminho circular que liga todas as casas, se espalhando como as ramas da Batata. A cantoria evolui, andando e parando em frente a cada casa, quando determinados personagens cerimoniais jogam as batatas naqueles que os desafiam. As cabeças da Batata provenientes da roça das mães dos hôxwa circulam pela aldeia, sendo proibido comê-las antes da festa, o que provocaria bolhas de pus e sangue pelo corpo dos jovens imprudentes. A Batata, que terá enfim suas cabeças transformadas em alimento, quer antes cantar e apresentar sua festa.

A análise que segue propõe um recorte em dois aspectos centrais dessa ação ritual: a dádiva-agressão com as cabeças da Batata (Melatti 1978), quando através das trocas das "coisas" tornam-se visíveis as próprias relações entre as "pessoas"; o canto-fala da Batata e a brincadeira dos palhaços- 
-Abóbora, que fazem escutar e visualizar uma multiplicidade de seres que co-habitam na roça e no Cerrado.

\section{Circulação ritual e o gênero da dádiva}

Apresentar-se na cantoria da Batata é uma prerrogativa ligada ao nome pessoal, estão presentes os keti / tyj (nominadores) e seus ipantu (nominados), evidenciando as relações de transmissão dos saberes rituais. Participam as cantoras da Batata (hõkrepoj), as velhas e as jovens, estas últimas também chamadas de "rainhas da Batata" (meninas-moças entrando na puberdade); os palhaços-Abóbora (hôxwa), que carregam os cofos cheios de batatas colhidas nas roças de suas parentes maternas; o Croá (parxô) e as Ramas (krô), que lançam as batatas nos desafiantes do cortejo musical, além dos mestres rituais (padlé) que tocam maracá e puxam a cantoria.

Nota-se que os "companheiros da Batata" são todos plantas de rama (ihkrô), enquanto seus oponentes são plantas de crescimento vertical (ihpàr): mandioca, banana, milho, mamão, cana etc. Assim, o Croá e as Ramas, acompanhando as cantoras da Batata e os palhaços-Abóbora, seguem "jogando e batendo" com as cabeças da Batata nos seus oponentes plantas-verticais. É comum também que joguem cabeças de croá, de inhame e até laranjas. A disputa ocorre apenas entre os homens; quando o desafiante é acertado, todos gritam "uhuhuhuh" e ele se retira, dando a vez ao próximo. As crianças correm de um lado para o outro, catando as cabeças caídas pelo chão, levando-as para suas casas.

Nos rituais krahô é recorrente a realização de jogos e brincadeiras caracterizados pelo enfrentamento, e as Festas de colheita da Batata e também do Milho, como já notara Melatti (1978), são marcadas pelo lançamento de projéteis que expressam o tom agonístico das trocas entre afins. Essas trocas evidenciam a "afinidade cerimonial", pensada aqui como uma versão jê daquilo que Viveiros de Castro denominou de "afinidade potencial" (2002 [1993]) ou "virtual" (2002), ressaltando as trocas que abrem o parentesco para a exterioridade, isto é, para além da afinidade atual efetivada pelo casamento e atraída para a consanguinidade.

As cabeças da Batata saem das roças das mães dos hôxwa e circulam pelas outras casas da aldeia, assim como os filhos homens que, ao casarem, saem da casa materna e passam a habitar a casa de suas esposas, seguindo a regra da uxorilocalidade. Em retribuição à cantoria, as mulheres de cada casa oferecem presentes - panos, colares de miçanga, panelas, copos, pratos - que são pendurados no corpo dos companheiros da Batata e imediatamente 
retirados pelos participantes da festa ou guardados, para serem posteriormente distribuídos entre os convidados de outras aldeias.

Para além da afinidade cerimonial masculina, relação expressa no enfrentamento entre as metades na corrida de toras e na cantoria da Batata, a festa evidencia as trocas entre as diferentes residências matrilocais, que são exogâmicas e constituídas por mulheres que descendem em linha feminina. Não se trata de meros grupos domésticos, mas de "pessoas morais" que se relacionam pela aliança e a circulação de seus aspectos partíveis, incluindo pessoas, nomes, alimentos, prerrogativas rituais, materiais e imateriais (Lea 1986, 2012). ${ }^{21}$ Essas trocas mobilizam especialmente o universo feminino, desconstruindo a clássica oposição entre os homens - associados ao centro da vida socioritual ligada às metades de pátio - e as mulheres - relegadas ao plano periférico e à esfera da "natureza" (Ladeira 1982). Como colocou Coelho de Souza, seguindo a crítica de Ladeira à concepção do sistema socioritual jê como centrado apenas no ponto de vista masculino:

[...] é igualmente legítimo vê-lo como fundado na circulação de maridos, ou pelo menos é assim que o concebem, aparentemente, as mulheres timbira (Ladeira 1982); certas práticas institucionalizadas inclusive expressam este ponto de vista (Coelho de Souza 2002:448).

Certas ações rituais e a forma assumida por elas fazem aparecer as relações e as identificações envolvidas nas trocas. Na Festa da Batata, as mães dos hôxwa se identificam com a Batata e com Caxêkwyj, ocupando a posição de "doadoras das cabeças-filhos" que circulam, vistos como "maridos" pelas casas tomadoras. Em convergência com a reflexão de Strathern (2006 [1988]) sobre as trocas no contexto melanésio, podemos sugerir que, no caso krahô, do ponto de vista das casas maternas doadoras e tomadoras, cuja relação se caracteriza pela afinidade feminina, o "gênero da dádiva" é masculino (filhos/irmãos/maridos). Simultaneamente, do ponto de vista dos afins cerimoniais masculinos, associados em "metades" que se enfrentam ritualmente, "o gênero da dádiva é feminino" (filhas/irmãs/esposas).

Como ressalta Strathern, o "gênero da dádiva", isto é, o comportamento assumido nas transações, não é neutro e nem previamente constituído, mas sim relacional. Ao tomar a forma-gênero feminina ou masculina, a relação de troca entre afins é de "mesmo sexo" (same sex). Já a relação entre o doador / tomador e a dádiva é de "sexo cruzado" (cross sex), ou seja, o que é desmembrado ou anexado na circulação pode assumir uma forma singular masculina ou feminina (Strathern 2006 [1988]:299-302). O ritual permite múltiplos pontos de vista, porém sempre parciais. 


\section{O canto-fala da Batata e os palhaços-Abóbora}

Vimos que as batatas medeiam o parentesco humano ao circularem pelas redes de troca e que o parentesco se estende para além do humano, tendo em vista que as relações humano-batata se caracterizam pelo aparentamento mútuo envolvendo criação, troca, nominação, transmissão de conhecimentos e predação. Para concluir, ressaltamos que, para além do par humano-planta, a Batata está inserida em emaranhados relacionais que abarcam outras(os) plantas, animais, seres e agencialidades. As manifestações estéticas e rituais são expressões dessa diversidade tão valorizada pelos Krahô, como podemos perceber no canto-fala da Batata e na performance dos palhaços-Abóbora, por meio dos quais uma multiplicidade de seres se apresenta.

"Jàt Jarkwa" é como os Krahô chamam o que traduzimos por "canto-fala da Batata". Jarkwa (kwa: "boca") é como se referem à linguagem falada dos humanos (mẽhĩjarkwa), mas também das plantas e dos animais que possuem seu próprio jarkwa. A fala desses outros seres, do ponto de escuta mẽhi, podem ser cantos (inkrer) capturados, encorporados e entoados nos rituais. Cantos-falas implicam, portanto, relações que permitem diferentes pontos de fala e de escuta. A versão do canto-fala da Batata transcrita abaixo foi cantada pelo mestre ritual Olegário Tejapôc Krahô:

$\begin{array}{ll}\text { cahi jê jôhã johã hã } & \text { as pernas vamos movimentar jôhã } \\ \text { cahi jê jôhã johã hã } & \text { as pernas vamos movimentar jôhã } \\ \text { cahi jê } & \text { as pernas vamos movimentar } \\ \text { hê pàràre } & \text { ei torinha } \\ \text { ina cawỳ } & \text { vem nos mostrar } \\ \text { cahi jê jôhã johã hã } & \text { as pernas vamos movimentar jôhã } \\ & \\ \text { henẽ jarêttê } & \text { enterra a pedra } \\ \text { joweti hô hô hô hô } & \text { pelo, pelo, pelo, pelo de borboleta } \\ \text { henẽ jarêttê } & \text { enterra a pedra } \\ \text { joweti hô hô hô hô } & \text { pelo, pelo, pelo, pelo de borboleta } \\ \text { henẽ jarêttê } & \text { enterra a pedra } \\ \text { joweti hô hô hô hô } & \text { pelo, pelo, pelo, pelo de borboleta } \\ \text { mã cycycyre he } & \text { cantando cycycyre he } \\ \text { mã cycycyre he } & \text { cantando cycycyre he } \\ \text { mã cycycyre } & \text { cantando cycycyre } \\ \text { mã cycycyre he } & \text { cantando cycycyre he } \\ \text { mãjõ prãrãre he } & \text { anda caçando por aí } \\ \text { mã cycycyre he } & \text { cantando cycycyre he } \\ \text { mãjõ prãrãre he } & \text { anda caçando por aí }\end{array}$




\begin{tabular}{|c|c|}
\hline mã Cajkritire he & levinha he \\
\hline mã Cajkritire he & levinha he \\
\hline mã Cajkritire & levinha he \\
\hline mã Cajkritire he & levinha he \\
\hline mã kwỳ kjnĩre he & gosta de roça queimadinha \\
\hline mã Cajkritire he & levinha he \\
\hline mã kwỳ kjnĩre he & gosta de roça queimadinha \\
\hline mãtê curàtê hê & filhote de lagartixa he \\
\hline mãtê curàtê hê & filhote de lagartixa he \\
\hline mãtê curàtê & filhote de lagartixa \\
\hline mãtê curàtê hê & filhote de lagartixa he \\
\hline mãtê nõ te hê & deitadinho \\
\hline mãtê curàtê hê & filhote de lagartixa he \\
\hline mãtê nõ te hê & deitadinho \\
\hline mã hôjpiare he & cantando hôjpiare he \\
\hline mã hôjpiare he & cantando hôjpiare he \\
\hline mã hôjpiare & cantando hôjpiare \\
\hline mã hôjpiare he & cantando hôjpiare he \\
\hline mã pari hôrôre he & da perninha queimadinha \\
\hline mã hôjpiare he & cantando hôjpiare he \\
\hline mã pari hôrôre he & da perninha queimadinha \\
\hline mã xêwxêterê he & arraiazinha $h e$ \\
\hline mã xêwxêterê he & arraiazinha $h e$ \\
\hline mã xêwxêterê & arraiazinha \\
\hline mã xêwxêterê he & arraiazinha $h e$ \\
\hline mã pic torore he & escondidinha \\
\hline mã xêwxêterê he & arraiazinha $h e$ \\
\hline mã pic torore he & escondidinha \\
\hline wa ri cô juwê hêhêhê & olha a chapada juwê hêhêhê \\
\hline wa ri cô juwê hêhêhê & olha a chapada juwê hêhêhê \\
\hline wa ri cô juwê & olha a chapada juwê \\
\hline wa ri cô juwê hêhêhê & olha a chapada hêhêhê \\
\hline wa ri cô juwê & olha a chapada juwê \\
\hline wa ri cô juwê hê & olha a chapada juwê hê \\
\hline wa ri côjuwê & olha a chapada juwê \\
\hline
\end{tabular}




\begin{tabular}{|c|c|}
\hline narêja & arrancando \\
\hline narê ja he he & arrancando he he \\
\hline nare ja & arrancando \\
\hline narê ja he he & arrancando he he \\
\hline narêja & arrancando \\
\hline hô ryre & a folha compridinha \\
\hline narêja & arrancando \\
\hline hô ryre & a folha compridinha \\
\hline hija hajô cô & quebradinha de joelho \\
\hline hija hajô cô & quebradinha de joelho \\
\hline pere & pra dança ficar bonita \\
\hline hija hajô cô & quebradinha de joelho \\
\hline pere & pra dança ficar bonita \\
\hline hija hajô cô & quebradinha de joelho \\
\hline jahê tê tê têe hê & andando hê \\
\hline jahê tê tê & andando \\
\hline jahê tê tê têe hê & andando hê \\
\hline jahê tê tê & andando \\
\hline jahê tê tê têe hê & andando hê \\
\hline hôwa ja mẽ to tẽ hê & os hôxwa já vêm chegando \\
\hline hôwa ja mẽ to tẽ hê & os hôxwa já vêm chegando \\
\hline jahê tê tê & andando \\
\hline
\end{tabular}

O canto não é "sobre", mas "da" Batata, cuja perspectiva é multiplicada em outros pontos de vista e de fala. O canto faz escutar e visualizar os mundos celeste, terrestre e aquático habitados por seres diversos, explicou Olegário Tejapôc na ocasião da tradução: o Gaviãozinho que canta cycycyre, andando e caçando suas presas por aí; o pelo-doença da Borboleta que cega e, em sua forma-pedra, precisa ser enterrado para não sair; o Sabiazinho da perninha queimadinha que canta hôjpiare; o filhote da Lagartixa que fica na casa da roça deitadinho; a Arraia camuflada no fundo do rio, pronta para ferir com seu ferrão os descuidados; a folha compridinha da Mandioca brava arrancada na roça; a Batata que é levinha e gosta da roça queimadinha; o jeito de dançar animado e sensual das mulheres, fazendo uma "quebradinha de joelho"; o caminhar das ramas, da Batata-cantora e dos palhaços-Abóboras.

O canto-fala da Batata chama a atenção por sua concisão semântica, pelas transformações fonológicas sofridas pela palavra ritual, pelo uso intensivo de onomatopeias e vocalizes, metáforas e duplos sentidos, assim como 
por sua dinâmica entre repetição e variação. Como colocou Tugny (2009a, 2009b, 2011) em relação aos cantos dos povos Morcego e Gavião entoados pelos Maxakali, cujas características formais e poéticas permitem aproximações com os cantos krahô, tampouco o canto da Batata simplesmente expressa comentários ou observações bucólicas sobre o que é visto ou ouvido, mas sim uma multiplicidade de sujeitos-enunciadores que cantam seu jeito de ser, suas qualidades sensíveis e afecções corporais, estados e movimentos. Esses diferentes pontos de vista são igualmente experenciados pela pessoa do cantor-especialista (Cesarino 2006, 2011).

Eles [os cantos] são o próprio estado de sujeito de cada coisa, sua potência subjetiva. São mais do que visão, são captura de força (o deslocamento, a gravidade, a impedância) [...] um povo-espírito, que canta ao percorrer o mundo. Canta, inquirindo sobre cada uma de suas dobras. [...] Quando canta, vertiginosamente o seu mundo se desdobra e desdobram-se os enunciadores (Tugny et al. 2009a:15).

A cantoria sai da casa ao norte e segue, andando e cantando, parando e jogando batatas, se espalhando pelo caminho circular (krincape) como as ramas da Batata. Ao chegar à altura da casa mais a leste, a cantoria adentra pelo caminho radial (prykarã) e irrompe pelo pátio central (kà), quando se aproxima do seu fim. O sol se despede com o cair da noite, é então chegada a hora dos hôxwa, que se reúnem prontamente na casa a oeste para darem início a sua metamorfose ritual. Ninguém pode vê-los se pintando e vestindo seus adereços, que conferem o tom grotesco de sua graça. Enquanto se preparam, suas mães e parentes maternas fazem uma grande fogueira no pátio, em torno da qual o público aguarda.

O pátio é então invadido por esses seres estranhos, meio bicho, meio gente, meio planta ou qualquer outra coisa. Seres andrógenos, que transitam para além das fronteiras do humano. Eles chegam com pinturas brancas, que desfiguram o corpo, muito diferentes daquelas feitas com jenipapo e urucum. Usam folhas na cabeça, ou ainda máscaras feitas de cabaça e pelos de animais.

Os hôxwa não falam e nem cantam: "o hôxwa não fala com a boca, fala com a cena. A cena é a imitação. Com a mão, com o corpo", disse o hôxwa Tadeu Cajhy Krahô. Eles são acompanhados pelos Croá (parxô) e Gaviãozinhos (hàcre), que ficam no pátio tocando maracá (coité) e flauta (krure). O som dos instrumentos chama os hôxwa ao pátio para brincarem na fogueira. Eles entram no pátio e apresentam seus esquetes. Tornam a sair pelo caminho radial até a casa a oeste, e depois voltam novamente, o que se repete várias vezes. A formação espacial da apresentação é circular, 
eles se movimentam em fila, rodeando a fogueira. O andar é ritmado, como uma dança. O mais velho é quem comanda a brincadeira, seus "cabeças novas" o imitam. E nessa repetição o comportamento se renova, criando variadas nuances e diferenças estilísticas, através das quais se imprime a marca pessoal de cada hôxwa.

Hôxwa significa "folha amarga". A pintura branca provoca estranheza, revelando um corpo aberto, inacabado e imperfeito. Remete às manchas da abóbora, às pintas da onça, à cor dos espíritos e do branco. Sua barriga é estufada e redonda como a abóbora, a cabaça e a mulher grávida. As primeiras mulheres foram feitas da cabaça, onde são guardadas as sementes para o plantio. O nome para abóbora é cuhkõn cahàc, "falsa cabaça", pois "parece, mas não é", "apenas engana". Assim são também os próprios mẽcarõ, espíritos-imagens enganadores, caracterizados por sua natureza transformativa. Cabe notar que a dúvida e a ambiguidade são artifícios centrais da moldura da brincadeira que, como colocou Bateson (1972), cria antes um contexto de enunciação do que uma mensagem em si.

A pintura confere ao corpo do hôxwa o aspecto de uma "figura-desfigurada", que não se dissipa totalmente em abstração, mas também não constitui identidade fixa (Deleuze 2007). Ele não "é", ele "imita/vira" alguma coisa, sua condição é transitória. Na língua krahô, a expressão "amjĩ to" designa os atos de "imitar/virar" associados aos regimes de metamorfose que ocorrem no contexto mítico-ritual. A noção de "imitar/virar" não apresenta uma clivagem representativa essencial, em termos de uma separação entre a ficção e o real. A mimese do hôxwa também não reproduz verossimilhança, ao contrário, produz excessos e marca as diferenças em relação às figuras da alteridade retratadas de maneira cômica, grotesca e risível.

Os hôxwa imitam posições sexuais, fazendo brincadeiras jocosas em torno do baixo corporal, homens que se travestem de mulher. Eles não têm vergonha ou respeito (pahàm), a gula por comida e sexo é uma temática recorrente. Imitam bêbados cambaleantes com garrafas de cachaça nas mãos. Dançam forró agarradinho e ironizam os brancos com suas máquinas em punho tirando fotos freneticamente. Brincam com o comportamento de certos animais, como as onças, ameaçando jogar fogo na plateia. Uma conexão central, entretanto, é com o comportamento das plantas, explica Tadeu Cajhy:

Quando a Batata se prepara, a Abóbora tem direito de fazer esse rito que nós estamos fazendo, de mostrar como é que faz. Cada giro é uma planta que faz. Tem planta boa, que fala manso. Tem planta azeda, que fala meio imprensado. Tem planta que é amargoso que fala agitado. Tudo é jeito das plantas. Quando hôxwa faz assim, não é ele em pessoa. Ele está mostrando o que significa aquilo. Talvez é a Abóbora... Quando levanta o pé assim e sai só com um, é imitando a planta, esses de rama. Porque é bem enramado, uma parte ela segura com o 
pé pra um lado e com o outro os braços. Isso tudo rito que nós faz é rito dessa planta. Nós acredita nas plantas. Nós acredita nas plantas porque ele primeiro vai pra terra e depois que vai salvar nós. Porque se nós não acreditasse, ele ia pra terra e lá mesmo ficava... (Tadeu Cahhy Krahô, transcrição trecho filme Hotxua, de 2007).

Por fim, observamos que a mimese dos palhaços-Abóbora e a imagética do canto da Batata se complementam, traduzindo um engajamento estético, multissensorial e perspectivista com o mundo. As artes verbo-musicais e performáticas articulam noções próprias aos modos de conhecimento indígenas, indissociáveis dos processos corporais, da vida dos sentidos, de uma estética da ação, do gesto e do movimento (Overing 2006). O conhecimento é "encorporado", relacional e situado, fundamentado na apreensão das qualidades, dos hábitos e comportamentos que alicerçam disposições corporais específicas. ${ }^{22}$

"Tudo é jeito das plantas", coloca Tadeu Cajhy Krahô. E, "se cada planta tem seu jeito", para saber-fazer uma roça, cultivar ou manejar uma planta, é preciso entender a "imitação", a "fala", a "cultura" dela, como podemos concluir, com as palavras de Getúlio Kruakraj Krahô:

O hôxwa era a Abóbora, o espírito da Abóbora que virou gente. O hôxwa não é do mẽhĩ, ele é do mecarõ. O hôxwa não é pajé, ele é espírito, que o mẽhĩ que era pajé viu e aprendeu com ele. As plantas têm alma, elas são gente, têm fala. A gente é que não entende mais, só quem é pajé.

Vocês vêm aqui fazer estudo, são estagiários, querem aprender. Ficam vendo as mulheres furando tiririca, fazendo o tucum, enfiando na semente. Perguntam como colhe tiririca, qual o tempo que dá, tiram fotos. Aí chega lá no mundo dos brancos e falam tudo, mostram as fotos. As fotos são a prova de que você foi lá e aprendeu.

Mas será que você vai entrar no mato e tirar tiririca? Ir afastando o mato com o pau pra não se cortar? Será que você sabe furar ela, ficar com os dedos todo ralado? Será que você sabe enfiar o tucum? Sabe nada... Pra aprender sobre aquele pé de coco ali, você tem que entender a imitação, a fala, a cultura dele. O hôxwa é a imitação das plantas. Cada planta tem seu jeito, sua imitação. [...]

A planta tem vento, tem respiração. A raiz dela fica embaixo da terra, mas quando ela cresce, o vento bate, ela balança, tem movimento. Planta sem galho, sem vento, sem movimento é planta que não cresce, que fica embaixo da terra. A imitação dos hôxwa é a imitação das plantas, que balançam quando o vento bate... 
Recebido em 18 de novembro de 2016

Aprovado em 10 de julho de 2017

Ana Gabriela Morim de Lima é doutora em Antropologia pelo Programa de Pós-Graduação em Sociologia e Antropologia, Universidade Federal do Rio de Janeiro, Rio de Janeiro, RJ, Brasil. E-mail: > morimdelima@gmail.com> 


\section{Notas}

1 Este artigo sintetiza algumas das principais ideias desenvolvidas em minha tese de doutorado (Morim de Lima 2016). Como a batata-doce, ele se ramifica e envereda por vários caminhos que tentam dar conta dos diferentes aspectos ligados ao ciclo de vida da batata-doce de modo mais amplo. Em artigos futuros, pretendo abordar e me deter em cada um desses aspectos em particular. Aproveito para agradecer Joana Cabral de Oliveira e Ian Packer pelos comentários feitos numa versão prévia deste artigo.

2 A batata-doce é uma espécie da família Convolvulacae, que agrupa 50 gêneros, entre os quais Ipomoea, com 700 espécies. O cultivo da batata-doce remonta há mais de 10.000 anos, a América é aceita como seu centro de origem, sendo o México e a América Central as regiões que apresentam maior diversidade genética. Atualmente é cultivada em mais de 100 países, em locais de climas diversos, como a Cordilheira dos Andes, a Amazônia, o Cerrado, o sul do Brasil, a costa do Pacífico e a Ásia (Silva 2008).

3 Sobre as formas de classificação krahô e os nomes das variedades locais, ver Morim de Lima (2016).

4 No escopo da reflexão sobre as espécies companheiras, sejam plantas, animais, organismos, coisas ou outros seres animados que compartilham suas vidas com os humanos, desenvolveu-se a proposta da "etnografia multiespécie". Para aprofundar a discussão, ver a revisão bibliográfica de Arruda Campos (2016) sobre as principais referências dos estudos da etnografia multiespécie (Kirksey \& Helmereich 2010; Ogdon et al. 2013; Dransart 2013; Tsing 2013, 2015, Van Dooren 2014; Kirksey 2015; Van Dooren, Kirksey \& Münster 2016 apud Arruda Campos 2016) à luz dos quais a autora propõe uma etnografia multiespécie das mandiocas cultivadas pelos Pataxó. Ver também o diálogo entre a abordagem multiespécie e a etnografia do cultivo das mandiocas pelos Wajãpi em Cabral de Oliveira (2017).

5 Ver Descola (1986); Taylor (2000); Rival (2001); Belaunde (2001); Ewart (2005); Lagrou (2007); Emperaire et al. (2010); Cabral de Oliveira (2006, 2012); Maizza (2014); Miller (2015).

6 Para ver as transcrições na língua, consultar Morim de Lima (2016).

7 Não existe um termo genérico na língua para "planta". O reino vegetal, que em nossa ontologia naturalista corresponderia ao táxon científico Plantae, não aparece nomeado.

8 No caso dos nomes inalienáveis, o possuidor é indicado por um nominal ou por um prefixo pronominal, precedido ou não por um prefixo relacional: jàt krã ("cabeça da batata") ou ikrã ("minha cabeça"), akrã ("tua cabeça"), ihkrã ("cabeça de alguém"). No caso dos alienáveis, o possuidor é indicado por um nominal ou por um prefixo pronominal seguido pela posposição do genitivo -õ: jó jàt (minha batata); ajõ jàt (tua batata); hõ jàt (sua batata). 
9 O pahhi de uma aldeia diante de outras aldeias; a pahhi das mulheres em face dos homens; o pahhi das batatas ou dos veados em relação aos coletivos humanos ("mẽhĩ").

10 A questão foi desenvolvida também por Anne-Christine Taylor (2000) sobre a relação caça masculina-cultivo feminino entre os Ashuar e Laura Rival (2001) sobre a relação sementes-clones entre os Makushi.

11 Na língua krahô, a ação de "arrancar batata" se traduz por "jàt jarê", algumas vezes (especialmente na linguagem metafórica dos cantos) também aparece como "caçar", "jàt jahêr".

12 Trata-se do cofo ou càhà ("caahà xà": útero), cesto cargueiro feminino que objetifica a agência e a forma uterina: invólucro que transporta e guarda os alimentos da roça.

13 Ver Seeger (1981); Borges e Niemeyer (2012).

14 Entre os estudos jê, ver Coelho de Souza (2002), Gordon (1996, 2006), Borges e Niemeyer (2012), Demarchi (2014), entre outros.

15 Os Krahô possuem terminologias Crow-Omaha. O nominador ("keti"| "tyj") transmite um conjunto de nomes ao nominado ("ipantu").

16 A autora coloca sobre a "troca de nomes e cônjuges": "os laços entre os parentes patrilaterais dispersos pelos diferentes segmentos da aldeia podem ser reforçados pela nominação, que impede que estes se transformem em afins. Quando não ocorre a nominação, o casamento se torna possível" (Ladeira 1982:52).

17 Não existe um termo específico para corpo, o que nos leva a sugerir, como já fizeram outros autores, o termo aproximativo de $n \tilde{\imath}$ (carne).

18 De acordo com Melatti (1978:14): “[a palavra amjīkin] pode ser usada em frases tais como i mã amnikhĩ, 'eu estou alegre'. José Aurélio, da mesma aldeia, traduziu amnikhĩ por 'gostar', mas segundo Penõ, 'gostar' é khĩ, como se pode ver na frase i mã khĩ, 'eu gosto'."

19 Desde a etnografia de Nimuendajú; a clássica reflexão sobre o dualismo diametral e concêntrico de Lévi-Strauss (1974 [1952]); os estudos dos pesquisadores do Harvard Central Brazil Project - ver especialmente a compilação Dialectical Societies organizada por Maybury-Lewis (1979), as etnografias de DaMatta (1976) e Melatti (1970) - e as revisões contemporâneas de Marcela Coelho de Souza (2002) e Cesar Gordon (1996).

20 Ver a etnografia detalhada da Festa da Batata em Morim de Lima (2016).

21 A partir de uma releitura do conceito de "sociedade de casas" (Lévi-Strauss 1984 apud Lea 2012), Vanessa Lea desenvolveu a noção de Casa para os Mẽbêngôkre.

22 Ver o conceito de body knowledge desenvolvido por Kessinger (1995) na etnografia Pano, e mais especificamente nos trabalhos de Lagrou (2007) e McCallum (2001). 


\section{Referências bibliográficas}

ARRUDA CAMPOS, Marilena Altenfelder. 2016. Na roça com os Pataxó: etnografia multiespécie da mandioca na aldeia Barra Velha do Monte Pascoal, Sul da Bahia. Tese de Doutorado, Universidade de São Paulo.

AZANHA, Gilberto. 1984. A forma timbira: estrutura e resistência. Dissertação de Mestrado, Universidade de São Paulo.

BATESON, Gregory. 1972. "A theory of play and fantasy". In: J. Aronson (org.), Steps to an ecology of mind. London/San Francisco/Scranton/Toronto: Chadler Publishing Company. pp. 177-193.

BELAUNDE, Luisa Elvira. 2001. Viviendo bien. Gênero y fertilidad entre los Airo-Pai de la Amazônia peruana. Lima: CAAAP. 2006. "A força dos pensamentos, o fedor do sangue. Hematologia e gênero na Amazônia". Revista de Antropologia, 48(1):205-243.

. 2008. El recuerdo de Luna. Género, sangre y memoria entre los pueblos amazónicos. Lima: Centro Amazónico de Antropologia y Aplicación Prática.

BORGES, Julio Cesar. 2004. O retorno da velha senhora: a categoria tempo entre os Krahô. Dissertação de Mestrado, Universidade de Brasília.

.; NIEMEYER, Fernando. 2012.

"Cantos, curas e alimentos: reflexões sobre regimes de conhecimento krahô". Revista de Antropologia, 55(1):255-290.

CABRAL DE OLIVEIRA, Joana. 2006. Classificações em cena: algumas formas de classificação das plantas cultivadas pelos Wajãpi do Amapari (AP). Dissertação de Mestrado, Universidade de São Paulo.
. 2012. Entre plantas e palavras. Modos de constituição de saberes entre os Wajãpi. Tese de Doutorado, Universidade de São Paulo. . 2017. "A sedução das mandiocas". In: B. C. Labate; S. L. Goulart (orgs.), O uso de plantas psicoativas nas Américas. Campinas: Editora Mercado de Letras [no prelo].

CARNEIRO DA CUNHA, Manuela. 1978. Os mortos e os outros. Uma análise do sistema funerário e da noção de pessoa krahó. São Paulo: Editora Hucitec.

. 2009. Cultura com aspas e outros ensaios. São Paulo: Cosac \& Naify.

CASTRO ALVES, Flávia. 2004. O Timbira falado pelos Canela Apãniekrá: uma contribuição aos estudos de morfosintaxe de uma língua Jê. Tese de Doutorado, Universidade Estadual de Campinas.

CESARINO, Pedro de Niemeyer. 2006. “De duplos e estereoscópios: paralelismo e personificação nos cantos xamanísticos ameríndios". Mana. Estudos de Antropologia Social, 12(1):105-134.

. 2011. Oniska: poética do xamanismo na Amazônia ocidental. São Paulo: Perspectiva / Fapesp.

COELHO DE SOUZA, Marcela Stockler. 2002. O traço e o círculo: o conceito de parentesco entre os Jê e seus antropólogos. Tese de Doutorado, Universidade Federal do Rio de Janeiro.

COSTA, Luiz. 2007. As faces do jaguar. Parentesco, história e mitologia entre os Kanamari da Amazônia Ocidental. Tese de Doutorado, Universidade Federal do Rio de Janeiro. . 2010. "The Kanamari body-owner: predation and feeding in western Amazonia". Journal de la Société des Américanistes, 96(1):169-192. 
CROCKER, William H. 1977. "Canela 'group' recruitment and perpetuity: incipient 'unilineality'?". In: J. Overing Kaplan (org.), Actes du XLII Congrès International des Américanistes (Paris 1976). Vol. II. Paris: Société des Américanistes. pp. 259-275.

. 1990. The Canela (Eastern Timbira), I: an ethnographic introduction. Washington, D.C.: Smithsonian Institution Press (Smithsonian Contributions to Anthropology, 33).

.; CROCKER, Jean. 2009. Os Cane-

las. Parentesco, ritual e sexo em uma tribo da Chapada Maranhense. Rio de Janeiro: Museu do Índio-Funai.

DAMATTA, Roberto. 1976. Um mundo dividido: a estrutura social dos Apinayé. Petrópolis: Vozes.

DELEUZE, Gilles. 2007 [1981]. Lógica da sensação. Rio de Janeiro: Jorge Zahar Editor.

DEMARCHI, André. 2014. Kukràdjà Nhipêjx: fazendo cultura. Beleza, ritual e políticas da visualidade entre os Mebêngôkre (Kayapo). Tese de Doutorado, Universidade Federal do Rio de Janeiro.

DESCOLA, Philippe. 1986. La nature domestique: symbolism et praxis dans l'écologie des Achuar. Publié par la Fondation Singer-Polignac. Paris: Ed. de la Maison des Sciences de L'Homme.

. 2005. Par-delà nature et culture. Paris: Gallimard.

EMPERAIRE, Laure (org.). 2010. Dossiê de registro do Sistema Agrícola Tradicional do Rio Negro. Brasília: ACIMRN / IPHAN / IRD / Unicamp-CNPq.

EWART, Elisabeth. 2005. "Fazendo pessoas e fazendo roças entre os Paraná do Brasil Central". Revista da Antropologia, 48(1):9-35.

FAUSTO, Carlos. 2002. "Banquete de gente: comensalidade e canibalismo na Amazônia". In: Mana. Estudos de
Antropologia Social, 8(2):7-44. 2008. "Donos demais: maestria e domínio na Amazônia". Mana, Estudos de Antropologia Social, 14(2):329-366.

GORDON, Cesar. 1996. Aspectos da organização social Jê: de Nimuendajú à década de 90. Dissertação de Mestrado, Universidade Federal do Rio de Janeiro. . 2006. Economia selvagem: ritual e mercadoria entre os índios Xikrin-Mebêngôkre. São Paulo: Editora Unesp/ISA; Rio de Janeiro: Nuti.

GOW, Peter. 1997. "O parentesco como consciência humana: o caso dos Piro". Mana. Estudos de Antropologia Social, 3(2):39-66.

GUERREIRO, Antônio. 2015. Ancestrais e suas sombras: uma etnografia da chefia Kalapalo e seu ritual mortuário. Campinas: Editora da Unicamp.

HARAWAY, Donna. 2003. The Companion Species Manifesto: dogs, people, and significant others. Chicago: Prickly Paradigm.

INGOLD, Tim. 2000. The perception of the environment: essays on livelihood, dwelling and skill. London: Routledge.

KOHN, Eduardo. 2002. Natural engagements and ecological aesthetics among the Ávila Runa of lo Amazonian Ecuador. Ph.D. Dissertation, University of Wisconsin-Madison. . 2013. How forests think: toward an anthropology beyond the human. Berkeley: University of California Press.

KESSINGER. 1995. How Real People Ought To Live: The Cashinahua of Eastern Peru. Prospect Heights, IL: Waveland Press.

LADEIRA, Maria Elisa. 1982. A troca de nomes e a troca de cônjuges. Uma contribuição ao estudo do parentesco timbira. Dissertação de Mestrado, Universidade de São Paulo. 
LAGROU, Els. 2007. A fluidez da forma: arte, alteridade e agência em uma sociedade amazônica (Kaxinawa, Acre). Rio de Janeiro: Topbooks.

LAVE, Jean. 1971. "Some suggestions for the interpretation of residence, descent, and exogamy among the Eastern Timbira". Proceedings of the 38th International Congress of Americanists, Stuttgart-Munich 1968, 1971. pp. 341-345.

LEA, Vanessa. 1986. Nomes e nekrets Kayapó: uma concepção de riqueza. Tese de Doutorado, Universidade Federal do Rio de Janeiro. . 2012. Riquezas intangíveis de pessoas partíveis. São Paulo: Edusp. LÉVI-STRAUSS, Claude. 1974 [1952]. "Les organisations dualistes existente-elles?". Anthropologie structurale. Paris: Plon. pp: 99-128. . 1989 [1962]. O pensamento selvagem. Campinas, SP: Papirus. . 2004 [1964]. O cru e o cozido. São Paulo: Ed. Cosac Naify.

LIMA, Tânia Stolze. 1996. "Os dois e seus múltiplos: reflexões sobre o perspectivismo em uma cosmologia Tupi". Mana. Estudos de Antropologia Social, 2(2):21-47.

. 2002. "O que é um corpo?". Religião

e Sociedade, 22(1): 9-20 . 2005. Um peixe olhou pra mim: o povo Yudjá e a perspectiva. São Paulo: Editora Unesp/ISA; Rio de Janeiro: NUTI.

MAIZZA, Fabiana. 2014. "Sobre as crianças-plantas: o cuidar e o seduzir no parentesco Jarawara". Mana. Estudos de Antropologia Social, 20(3):491-518.

MAUSS, Marcel. 2003 [1923-24]. "Ensaio sobre a dádiva". In: Sociologia e antropologia. São Paulo: Cosac Naify. pp. 185-314.

MAYBURY-LEWIS, David. 1979. "Introdução"; "Conclusão: kinship, ideology, and culture". In: D. Maybury-
-Lewis (org.), Dialectical societies. The Gê and Bororo of Central Brazil. Cambridge, Mass.: Harvard University Press. pp. 1-15; 301-314.

McCALLUM, Cecilia. 2001. Gender and sociality in Amazonia: how real people are made. Oxford: Berg Press.

MELATTI, Julio Cezar. 1970. O sistema social Krahô. Tese de Doutorado, Universidade de São Paulo. . 1974a. "Por que a aldeia Krahó é redonda?". In: Informativo FUNAI, 11/12. Brasília: Funai. pp. 34-41. . 1974b. "Myth and shaman". In: Patricia J. Lyon (org.), Native South Americans. Boston: Little, Brown \& Co. pp. 267-275.

. 1976. "Nominadores e genitores: um aspecto do dualismo krahô". In: E. Schaden (org.), Leituras de etnologia brasileira. São Paulo: Cia. Editora Nacional. pp. 139-148. . 1978. Ritos de uma tribo timbira. São Paulo: Editora Ática.

MILLER, Theresa. 2015. Bio-sociocultural aesthetics: indigenous Ramkokamekra-Canela gardening practices and varietal diversity maintenance in Maranhão, Brazil. Ph.D. Dissertation, University of Oxford.

. 2015. "Valuing varietal diversity: indigenous Canela horticulture in northeast Brazil". Society, Biology \& Human Affairs, 78(1\&2):62-82.

MIRANDA, Maxwell. 2014. Morfologia e morfossintaxe da língua Krahô (família Jê, tronco Macro-Jê). Tese de Doutorado, Universidade de Brasília.

MORIM DE LIMA, Ana Gabriela. 2013. "Hôxwa: uma abordagem etnográfica dos palhaços cerimoniais Krahô". In: J. Urbano (org.), Revista Nada, 17:5580, Lisboa.

. 2016. "Brotou batata para mim" Cultivo, gênero e ritual entre os Krahô (TO, Brasil). Tese de Doutorado, Universidade Federal do Rio de Janeiro. 
NIMUENDAJÚ, Curt. 1946. The Eastern Timbira. Berkeley: University of California Press.

OVERING, Joanna. 2000. "Conviviality and the opening up of Amazonian anthropology". In: J. Overing; A. Passes (orgs.), The anthropology of love and anger: the aesthetics of conviviality in native Amazonia. Londres: Routledge. pp. 1-30.

. 2006. "O fétido odor da morte e os aromas da vida. Poética dos saberes e processo sensorial entre os Piaroa da Bacia do Orinoco". Revista de Antropologia, 49(1):19-54.

RIVAL, Laura. 2001. "Seed and clone: the symbolic and social significance of bitter manioc cultivation". In: L. M. Rival; N. L. Whitehead (orgs.), Beyond the visible and the material: the Amerindianization of society in the work of Peter Rivière. Oxford: Oxford University Press. pp. 57-80.

ROBERT, Pascale de; LÓPEZ GARCÉS, Claudia; LAQUES, Anne-Elisabeth; COELHO-FERREIRA, Márlia. 2012. "A beleza das roças: agrobiodiversidade Mebêngôkre-Kayapó em tempos de globalização". Boletim do Museu Paraense Emílio Goeldi, Ciências Humanas, $7(2): 339-369$.

SCHWARTZAMAN, Steve. 1988. The Panara of the Xingu National Park: the transformation of a society. Ph. D. Dissertation, University of Chicago. SEEGER, Anthony. 1980. Os índios e nós: estudos sobre sociedades tribais brasileiras. Vol. 6: Contribuições em ciências sociais. Rio de Janeiro: Editora Campus.

. 1981 Nature and society in Central Brazil: The Suya Indians of Mato Grosso, Cambridge: Havard University Press.

. 2015. Por que cantam os Kĩsêdjê. Uma antropologia musical de um povo amazônico. São Paulo: Cosac Naify.
SEEGER, Anthony; DAMATTA, Roberto; VIVEIROS DE CASTRO, Eduardo. 1987 [1979]. "A construção da pessoa nas sociedades indígenas brasileiras". In: J. Pacheco de Oliveira (org.), Sociedades indígenas e indigenismo no Brasil. Rio de Janeiro: Ed. Marco Zero. pp. 11-26.

STRATHERN, Marilyn. 2006. O gênero da dádiva. Campinas: Ed. Unicamp. . 2014. O efeito etnográfico e outros ensaios. São Paulo: Editora Cosac Naify.

SILVA, Lucielio Manoel da. 2008. Elementos do sistema reprodutivo de etnovariedades de batata-doce, provenientes do Vale do Ribeira, SP, Brasil. Dissertação de Mestrado, Escola Superior de Agricultura Luz de Queiroz, Piracicaba.

TAUSSIG, Michael. 1993. Mimesis and alterity. A particular history of the senses. New York / London: Routledge.

TAYLOR, Anne-Christine. 2000. "Le sexe de la proie. Représentations jivaro du lien de parenté". L'Homme, 154155:309-333.

TUGNY, Rosangêla Pereira de, Toninho Maxakali, Manuel Damaso Maxakali, Ismail Maxakali, Zé Antoninho Maxakali, Marquinhos Maxakali, Rafael Maxakali, Zelito Maxakali, Gilberto Maxakali (in memoriam). 2009a. Xũnĩm yõg kutex xi ãgtux hemex yõg kutex / Cantos e histórias do morcego- espírito e do hemex. Rio de Janeiro: Azougue.

TUGNY, Rosangêla Pereira de, Totó Maxakali, Zé de Ká Maxakali, Joviel Maxakali, João Bidé Maxakali, Gilmar Maxakali, Pinheiro Maxakali, Donizete Maxakali, Zezinho Maxakali, et al. 2009b. Mõgmõk Kutex / Cantos do gavial-espírito. Rio de Janeiro: Azougue.

TUGNY, Rosangêla Pereira de. 2011. Escuta e poder na estética Tikmũ'únMaxakali. Rio de Janeiro: Museu do Índio. 
TURNER, Terence. 1979. "Kinship, household, and community structure among the Kayapó". In: David Maybury-Lewis (org.), Dialectical societies: the Gê and Bororo of Central Brazil. Cambridge, Mass.: Harvard University Press. pp. 179-217.

VAN DOOREN, Thom. 2012. "Wild seed, domesticated seed. Companion species and emergence of agriculture". Philosophy, Activism, Nature, 9:22-28.

VIDAL, Lux. 1977. Morte e vida de uma sociedade indígena brasileira. São Paulo: Hucitec/Edusp.
VERNANT, Jean-Pierre. 1990. “Do duplo a imagem". In: Mito e pensamento entre os gregos: estudos de psicologia histórica. Rio de Janeiro: Paz e Terra. pp. 303-330.

VILAÇA, Aparecida. 1992. Comendo como gente. Rio de Janeiro: Editora UFRJ/Anpocs. . 2002. "Making kin out of others in Amazonia". The Journal of the Royal Anthropological Institute, 8(2):347365.

VIVEIROS DE CASTRO, Eduardo. 2002. A inconstância da alma selvagem. São Paulo: Ed. Cosac Naify.

\section{Filme}

"Hôtxuá", de Letícia Sabatella e Gringo Cardia, 2012. 


\section{A CULTURA DA BATATA-DOCE: CULTIVO, PARENTESCO E RITUAL ENTRE OS KRAHÔ}

\section{Resumo}

O artigo tematiza as relações de parentesco cotidianas e rituais entre humanos e plantas por meio de uma etnografia do ciclo de vida da batatadoce, cultivada pelos Krahô: desde o plantio, passando pelo crescimento, até a colheita, quando ocorre a "Festa da Batata". O "aparentamento" mútuo entre as batatas e seus donos humanos envolve engajamentos corporais, afetivos e estéticos, implicando relações sociais de criação, troca, predação, transmissão de conhecimento xamânico e ritual. As plantas cultivadas são sujeitos vivos e não meras entidades biológicas passivas às intervenções humanas. Elas fazem parte de emaranhados relacionais que abarcam outras plantas, animais e seres, o que se torna visível na vivência cotidiana nas roças e, particularmente, nos cantos e nas performances rituais. Os saberes e as práticas krahô revelam uma outra compreensão do cultivo das plantas, reflexão esta que acompanha a reconceitualização das noções de humanidade, natureza e cultura pela etnologia à luz das teorias indígenas.

Palavras-chave: Krahô; batata-doce; cultivo; parentesco; ritual.
SWEET POTATO CULTURE: GARDENING, KINSHIP AND RITUAL AMONGST THE KRAHÔ

\begin{abstract}
This paper examines quotidian and ritual kinship relations between humans and plants through an ethnography of the life cycle of the sweet potato, a crop cultivated by Krahô people: from planting and growing to harvesting, when the Sweet Potato Feast takes place. The mutual process of "becoming kin" between sweet potatoes and their human owners involves corporal, affective and aesthetic engagements that imply social interactions of raising, exchange, predation, transmission of shamanic and ritual knowledge. Cultivated plants are living subjects and not mere biological entities that remain passive to human interventions. They are embedded in relational entanglements that encompass other plants, animals and beings, which become visible in the daily life of gardens and, particularly, in ritual chants and performances. Krahô knowledge and practices reveal a different way of thinking about the gardening activities which follows the reconceptualization of humanity, nature and culture by Amazonian anthropology in dialogue with indigenous theories.
\end{abstract}

Key words: Krahô; sweet potato; gardening; kinship; ritual. 
LA CULTURA DE LA BATATA: CULTIVO, PARENTESCO Y RITUAL ENTRE LOS KRAHÔ

\section{Resumen}

El artículo tematiza las relaciones de parentesco cotidianas y los rituales entre humanos y plantas por medio de una etnografía del ciclo de vida de la batata, cultivada por los Krahô: desde la plantación, pasando por el crecimiento, hasta la cosecha, cuando ocurre la "Fiesta de la Batata". El proceso mutuo de "volverse parientes" entre las batatas y sus dueños humanos presupone un compromiso corporal, afectivo y estético, implicando relaciones de creación, cambio y depredación, así como de transmisión de conocimiento chamánico y ritual. Las plantas cultivadas son sujetos vivos y no entidades biológicas pasivas a las intervenciones humanas. Ellas forman parte de enmarañados de relaciones que abarcan otras plantas, animales y seres, lo que se hace visible en la vida cotidiana en los campos y, en particular, en los cantos y en las performances rituales. Los saberes y las prácticas krahô revelan otra comprensión de lo cultivo de las plantas, reflexión que acompaña la re-conceptualización de las nociones de humanidad, naturaleza y cultura por la etnología a la luz de las teorías indígenas.

Palabras clabe: Krahô; batata; cultivo; parentesco; ritual. 